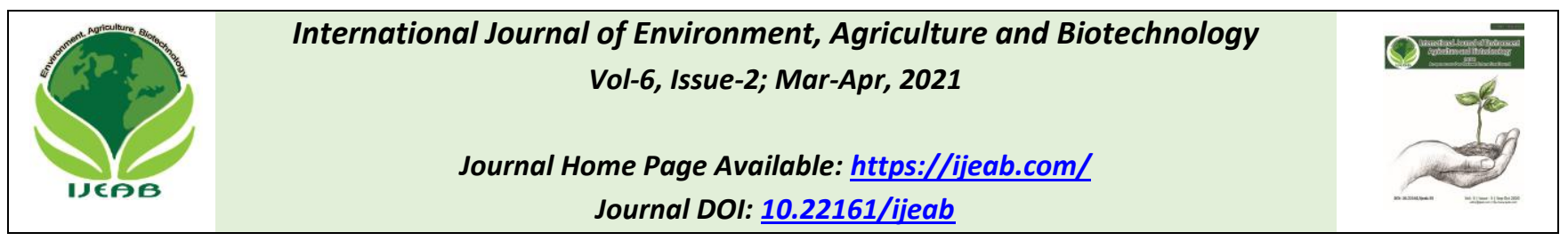

\title{
Nexus between Climate Change and Agricultural Production in Odisha, India: An ARDL Approach
}

\author{
Pratap Kumar Jena
}

Assistant Professor of Economics, Maharaja Sriram Chandra Bhanjdeo University, Baripada, Odisha-757003, India

Received: 19 Jan 2021; Received in revised form: 15 Mar 2021; Accepted: 03 Apr 2021; Available online: 23 Apr 2021

C2021 The Author(s). Published by Infogain Publication. This is an open access article under the CC BY license

(https://creativecommons.org/licenses/by/4.0/).

\begin{abstract}
Climate change is an emerging issue particularly in agricultural research as it is observed that the climate change has unfavorably distressed the agricultural production in different regions in India. Therefore, the present study has empirically examined the relationship between climate change and agricultural production in the selected districts of Odisha, India using a Panel Autoregressive Distributed Lag (PARDL) model over the period 1993 to 2019. The study found that the climate variables have adversely affected the crops production in the districts of Odisha. In order to minimize the impact of climate change on crops production in the state, there must have implementation of various policies and adaptive strategies by the government and farmers.
\end{abstract}

Keywords-Climate change, crops production, economic impact, central revenue zone Odisha.

\section{INTRODUCTION}

Climate change is an emerging issue for policy makers, scientists and academic researchers across the regions, since the impact of climate change varies from regions to regions, and have positive impact in some regions and negative in some other regions (Ninan and Bedamatta, 2012; Al-Amin et al., 2013). The existing studies on climate change have found a modest impact of climate change on developed countries, whereas the developing countries have a negative impact of such change (Mendelsohn and Dinar, 2003; Ciscar et al., 2012). The regions, which are located in tropical and sub-tropical climate, have realized more negative impact of climate change than others as it affects more to drier regions. ((Parry et al., 2007; Kurukulasuriya and Mendelson, 2006).

Empirical studies on the climate change and agricultural production have found a negative impact on developing countries, because the climate variables act directly along with input variables such as land, water, fertilizers \& pesticides, etc. in agricultural production (Cline, 2007; Xie et al., 2019). Though, the agriculture production is one the major sources of livelihood in rural areas of developing regions, the policy makers and researchers have given more importance to the impact of climate change on agricultural production in rural areas. The present study has intended to empirically examine the nexus between climate change and agricultural production in Odisha, India. Odisha is one of the poor and backward states situated in the East-Cost of India and in a climatic tropical zone, where we observe high temperature along with high humidity. The state economy and people's livelihood have extensively depend on agricultural \& its allied activities (Hoda et al., 2017). Since three/four decades, the agricultural production of the state has been highly affected by various climatic issues like; floods, droughts, storm, cyclones etc. (Rao et al., 2016). The agricultural production and yield have been declined over the years and stand as a major problem to food security in the state (Reddy, 2012). The state Odisha has been continuously influenced by different natural calamities such as cyclones, floods, or shortage of rainfall, etc, which badly hit the agricultural growth rate and livelihood of farmers. Therefore, the present study has made an attempt to examine the nexus between climate change and agricultural production in Odisha using an autoregressive Distributed Lag (ARDL) model. The rest of the paper is organized as follows; section-2 provides the review of literature. Section-3 describes study variables and 
methodology. Section-4 analyses the empirical results and the last section-5 provides the study conclusion.

\section{REVIEW OF LITERATURE}

A number of studies both at international and regional level have examined the impact of climate change on agriculture production or yield, that are broadly classified into two types; general equilibrium approach and partial equilibrium approach (Mishra et al. 2015). The general equilibrium approach or models have been used by many researchers, but the application of such models in developing and under developed countries are too less due to problems like data inconsistency and reliability, parameters specification, identification of model, etc. (Gillig and McCarl 2002; Zhai et al. 2009; Ciscar et al. 2002). As a result, the researchers have more relied on partial equilibrium approach in developing or under developed countries. The partial equilibrium approach is categorized into crop growth simulation model, and the econometric or Ricardian model (Deressa 2007). The economists and agricultural researchers prefer to use Ricardian model or econometric models to examine the impact of climate change on agriculture by taking into account of land revenues and values respectively. Ricardo uses the land value to measure net productivity, but for the first time Mendelsohn et al (1994) use the value of land to demonstrate the impact of climate change on agriculture of USA. Moreover, developing countries are lack of market information and difficult to get accurate land values, therefore, the annual net revenues per hectare has been used as a proxy by the researchers as it reflects the variation due to climate change (Dinar et al. 1998). The effect of climate change on the net crop yields per hectare is shown negative at national level (Chen et al. 2013). The high temperature affects negatively the net revenue from agriculture (Kaimakamis et al. 2013).

The climate change is measured by the climatic variables such as rainfall and temperature, and their impact depends on level of change in such variables. The extreme temperature and rainfall negatively affect crops production, while the minimum temperature and rainfall positively affect the crops production (Chowdhury and Khan 2015). Moreover, the low rainfall and high temperature could lead to raise of global food prices in future, and to avoid that problem, farmers should adopt coping mechanisms to resist from climate change (Rahman et al. 2018). In recent years, the global warming is one of the most harmful factors than precipitation (Mariara and Karanja, 2007).

In India, a continuous increase of the concentration of $\mathrm{CO} 2$ and other GHGs in the atmospheres lead to increase in the temperature and inconsistent rainfall which put a serious concern for agriculture \& allied activities (Bhattacharya and Panda, 2013). It is estimated that a $2^{0} \mathrm{C}$ increase in temperature and $7 \%$ increase in precipitation could lead to $8.4 \%$ decrease in the total net revenue from crops production (Kumar and Parikh, 1998). A common tendency of climate change is observed through the increase in average temperature, changes in rainfall timing and intensity (Putriawanti and ASAI, 2016). Studies suggested that the effects of climate change on agriculture in India can be tackled through proper irrigation, adaptation, diversifying the crops, and mitigation process, etc. (Birthal et al., 2014; Manoj et al., 2019). The climatic effects can also be cut off through increasing the marketing facilities, diversifying the crops, increasing various social security measures etc. (Mishra et al., 2015).

Climate studies on Odisha show that the climate change has a greater and severe impact on both the costal and western zone of Odisha. The deficits of rainfall and high temperature have negatively affected the agricultural production in the state (Panda et al. 2019). The relative magnitude of rainfall and temperature changes can be tackled by using appropriate mitigation, adaptation strategies, education to farmers on climate change and climate information (Mishra, 2017).

The above literature review indicates that the study on the impact of climate change on agricultural production has been growing, but still there is lack of regional studies particularly for Odisha. There is hardly any study, which analyzed the relationship between of climate change and agricultural production in the Central Revenue districts such as Nayagarh, Khorda, Puri, Jagatsingpur, Kendrapada, Cuttack, Jajpur, Bhadrak, Balasore, and Mayurbhanj of Odisha India. Therefore, the present study attempts to examine the nexus between climate change and the production of paddy and sugarcane in the selected districts of Odisha. In Odisha, paddy is the principal crops, which is produced at a larger quantities thn any crops by the farmers. Except that, sugarcane production has grown up in the study area as it gives good market value than other crops. Therefore, the resent study examine the nexus between climate change and crops production (paddy and sugarcane) in the selected districts of odisha.

\section{DATA AND METHODOLOGY}

The study has collected secondary data from ten selected districts of Odisha, which are from different agroclimate zones. The agro-climate zones of the state are categorized based on various components like soils, 
climate, topography, vegetation, crops, etc. The state Odisha has 10 major agro-climate zones, out of which the present study has collected data from North Central Plateau Zone (Mayurbhanj), North Eastern Coastal Zone (Balasore), East and South Eastern Coastal Zone (Bhadrak, Kendrapara, Jagtsingpur Cuttack, Puri, Khorda and Nayagarh), and Mid Central Table Land Zone (Jajpur). The details of the district agro-climate zones, climate, soils and suitable cropping system is reported in Appendix Table-1. The climatic variables such as rainfall and temperature data have been collected from the Indian Meteorological Department (IMD), Bhubaneswar for selected districts of Odisha from 1993 to 2019. The agricultural variables such as paddy and sugarcane productions, net shown area under crops, fertilizer consumptions data have been collected from the District Statistical Handbooks, Directorate of Agriculture and Statistics, Government of Odisha, India. The study selected crops i.e. paddy and sugarcane are largely produced by the selected districts of Odisha (Appendix Figure-1 \&2).

This paper has examined the nexus between climatic variables and agricultural production in Odisha using the Autoregressive Distributive Lag Model (ARDL) developed by Pesaran and Shin (1998) and Pesaran et al (2001). The ARDL model of co-integration test is more superior to other cointegration tests (i.e. Engle and Granger cointegration test (1987) and Johansen and Juselius cointegration test (1990)) for various reasons such as; the ARDL model consider the small sample size, simultaneity biases, and consider both $\mathrm{I}(0)$ and $\mathrm{I}(1)$ variable or both of mixed order of integration. The relationship between climatic variables rainfall and temperature and crops production in selected districts of Odisha, India is examined in the following specific model:

$A G C_{i t}=f\left(L A_{i t}, F C_{i t} R F_{i t} T E M P_{i t}\right)$

In the equation(1) $A G C_{i t}$ represents the agricultural crops production, i represents both crops Paddy and Sugarcane , $L A_{t}$ represents the land area or area under selected crops, $F C_{t}$ represents fertilizer consumption, $R F_{t}$ represents the rainfall, TEMP $P_{t}$ represents the average temperature in the study selected area respectively. The equation (1) can be written in the econometric form as follows:

$$
A G C_{i t}=\beta_{i 0}+\beta_{i 1} L A_{i t}+\beta_{i 2} F C_{i t}+\beta_{i 3} R F_{i t}+
$$

$\beta_{i 4} T E M P_{i t}+\mu_{i t}$

Since the study variables have different units of measurement, they may have multicollinearity and volatility, hence, for the better analysis of results, the study variables are transferred to their natural logarithm form, then the equation (2) become a log-linear model as follows:
$L n A G C_{i t}=\beta_{i 0}+\beta_{i 1} L n L A_{i t}+\beta_{i 2} L n F C_{i t}+\beta_{i 3} L n R F_{i t}+$ $\beta_{i 4} \operatorname{LnTEMP} P_{i t}+\mu_{i t}$

The ARDL model has two steps for estimation; first step, we examine the presence of a long-run relationship between the agricultural crops and study input variables are as follows:

$$
\begin{aligned}
\Delta \ln A G C_{i t}=\alpha_{0}+ & \sum_{j-1}^{p} \alpha_{1 i j} \Delta \ln A G C_{i t-k} \\
& +\sum_{j=1}^{p} \alpha_{2 i j} \Delta \ln L A_{i t-k} \\
& +\sum_{j=1}^{p} \alpha_{3 i j} \Delta \ln F C_{i t-k}
\end{aligned}
$$

$+\sum_{j=1}^{p} \alpha_{4 i j} \Delta \ln R F_{i t-k}$

$$
+\sum_{j=1}^{p} \alpha_{5 i j} \Delta \ln T E M P_{i t-k}+\beta_{1 i} \ln A G C_{i t-1}
$$

$+\beta_{2 i} \ln L A_{i t-1}+\beta_{3 i} \ln F C_{i t-1}+\beta_{4 i} \ln R F_{i t-1}+$ $\beta_{5 i} \operatorname{lnTEMP} P_{i t-1}+\varepsilon_{i t}$

Where, $\alpha_{0}$ represents as intercept tem, $\mathrm{p}$ represents the lag order, $\Delta$ stands for first difference operator of variables and $\varepsilon$ denotes the error term in the equation. The long-run equilibrium relationship between $\ln A G C, \ln L A, \ln F C$, $\ln R F$ and $\ln T E M P$ is examined using the Pesaran et al. (2001) given F-test. If the estimated F-test statistic lies above the upper level of band, there exists long-run relationship between the study variables and otherwise if the estimated F-test statistic lies below the upper level band. The relations are inconclusive if the computed F-test statistic lies between the lower and upper band. In the second step, we estimate the short-run relation between the study variables using th( ) error correction model (ECM) in ARDL model as follows:

$$
\begin{aligned}
& \Delta \ln A G C_{i t}=\alpha_{0}+\sum_{j-1}^{p} \alpha_{1 i j} \Delta \ln A G C_{i t-k}+ \\
& \sum_{j=1}^{p} \alpha_{2 i j} \Delta \ln L A_{i t-k}+\sum_{j=1}^{p} \alpha_{3 i j} \Delta \ln F C_{i t-k} \\
& +\sum_{j=1}^{p} \alpha_{4 i j} \Delta \ln R F_{i t-k}+ \\
& \sum_{j=1}^{p} \alpha_{5 i j} \Delta \ln T E M P_{i t-k}+\alpha E C M_{i t-1}+\varepsilon_{i t}
\end{aligned}
$$

The stationary condition of each variable is checked by the Levin, Lin and Chu's t-statistic.

\section{RESULTS AND DISCUSSIONS}

The descriptive statistics of the study variables are reported in Table-1, which indicates that, the study variables are normally distributed, whereas the variables such as production, net shown area, fertilizer consumption 
and rainfall are more volatile or fluctuate than the temperature of both paddy and sugarcane.

Table 1: Descriptive Statistics of Crops Production in the Study Area

\begin{tabular}{|lccccccccc|}
\hline \multicolumn{10}{|c|}{ PADDY } \\
\hline LNAGP & 12.05 & 12.13 & 13.44 & 9.53 & 0.72 & -1.34 & 5.37 & 144.55 & 0.00 \\
LNAL & 12.18 & 12.06 & 15.02 & 11.29 & 0.59 & 1.27 & 5.49 & 142.36 & 0.00 \\
LNFC & 8.12 & 8.01 & 10.73 & 4.96 & 1.35 & 0.05 & 1.75 & 17.66 & 0.00 \\
LNRF & 4.68 & 4.85 & 6.17 & 2.35 & 0.56 & -1.90 & 6.47 & 297.67 & 0.00 \\
LNTEMI & 3.25 & 3.29 & 3.58 & 2.86 & 0.13 & -0.52 & 2.65 & 13.67 & 0.00 \\
\hline & 18 & \multicolumn{10}{c}{ SUGARCANE } & & & & \\
\hline LNSP & 10.21 & 10.40 & 13.24 & 5.70 & 1.58 & -0.58 & 3.20 & 15.36 & 0.00 \\
LNSAL & 7.32 & 7.32 & 9.98 & 2.51 & 1.47 & -0.69 & 3.60 & 25.44 & 0.00 \\
LNSFER & 8.12 & 8.01 & 10.73 & 4.96 & 1.35 & 0.03 & 1.73 & 18.23 & 0.00 \\
LNRAIN & 4.68 & 4.85 & 6.17 & 2.35 & 0.56 & -1.90 & 6.47 & 297.63 & 0.00 \\
LNTEMI & 3.25 & 3.29 & 3.58 & 2.86 & 0.13 & -0.52 & 2.65 & 13.66 & 0.00 \\
\hline
\end{tabular}

Source: Author estimated

The correlation coefficient matrix are reported in Table-2, which indicates that both paddy and sugarcane productions are positively correlated to area, fertilizer consumption and temperature, whereas there is negative relations between crops production and rainfall, which is the preliminary indication of estimating cointegration between these variables.

Table 2: Correlation Results

\begin{tabular}{|lccccc|}
\hline \multicolumn{7}{c|}{ PADDY } \\
\hline LNAGP & LNAGP & LNAL & LNFC & LNRF & LNTEMP \\
LNAL & 1.00 & 0.17 & 0.16 & -0.09 & 0.05 \\
LNFC & 0.17 & 1.00 & 0.12 & 0.19 & 0.01 \\
LNRF & 0.16 & 0.12 & 1.00 & 0.00 & 0.05 \\
LNTEMP & -0.09 & 0.19 & 0.00 & 1.00 & 0.13 \\
\hline & 0.05 & 0.01 & 0.05 & 0.13 & 1.00 \\
\hline & \multicolumn{7}{c}{ SUGARCANE } & & \\
LNSP & LNSP & LNSAL & LNSFERT & LNRAIN & LNTEMP \\
LNSAL & 1.00 & 0.59 & 0.06 & -0.14 & 0.02 \\
LNSFERT & 0.59 & 1.00 & -0.22 & -0.04 & 0.05 \\
LNRAIN & 0.06 & -0.22 & 1.00 & -0.08 & 0.07 \\
LNTEMP & -0.14 & -0.04 & -0.08 & 1.00 & 0.13 \\
SOUFe: A A & 0.02 & 0.05 & 0.07 & 0.13 & 1.00 \\
\hline
\end{tabular}

Source: Author estimated

The cointegration between the crops productions and input variables such as net shown area, fertilizer consumption, rainfall and temperature are examined using the ARDL model, for which the stationary test is compulsory for each variable, and the stationary is checked using the Levin, Lin and Chu's t-statistics (Table-
3). The estimated Levin, Lin and Chu's t-statistics indicates that all the study variables are stationary at $\mathrm{I}(0)$ and I(1), which indicates to use the ARDL model for the analysis of long-run equilibrium relationship between crops production and input variables.

Table 3: Results of Unit Root Test

\begin{tabular}{|c|c|c|c|c|c|}
\hline \multirow{2}{*}{ Crops } & \multirow{2}{*}{ Variables } & \multicolumn{2}{|c|}{ Level Value } & \multicolumn{2}{c|}{ First Difference) } \\
\cline { 3 - 6 } & & Statistic & Prob.** & Statistic & Prob.** \\
\hline \multirow{2}{*}{ Paddy } & LNPP & $-3.81^{*}$ & 0.00 & & \\
& LNAP & $4.21^{*}$ & 0.00 & & \\
\cline { 3 - 6 } & & &
\end{tabular}




\begin{tabular}{|c|c|c|c|c|c|}
\hline & LNFC & -0.83 & 0.20 & $-15.20^{*}$ & 0.00 \\
& LNRF & $-2.47^{* *}$ & 0.01 & & \\
& LNTEMP & -0.79 & 0.22 & $-13.48^{*}$ & 0.00 \\
\hline \multirow{5}{*}{ Sugarcane } & LNSP & $-1.75^{* *}$ & 0.04 & & \\
& LNAS & 3.75 & 1.00 & $-4.40^{*}$ & 0.00 \\
& LNFC & -1.59 & 0.06 & $-5.72^{*}$ & 0.00 \\
& LNRF & $-2.49^{* *}$ & 0.01 & & \\
& LNTEMP & $-22.02^{*}$ & 0.00 & & \\
\hline
\end{tabular}

Source: Author estimated

The estimation of ARDL model needs to use appropriate lag-length, which is determined by the optimum lag-length criteria and the results are reported in Table-4.

Table 4: Lag Order Selection for Study Variables

\begin{tabular}{|c|c|l|l|l|l|}
\hline Crops & Lag & FPE & AIC & SC & HQ \\
\hline Paddy & 0 & 0.00 & 7.73 & 7.80 & 7.76 \\
& 1 & 0.00 & 4.57 & $4.00^{*}$ & 4.74 \\
& 2 & $0.00^{*}$ & $4.38^{*}$ & 5.15 & $4.69^{*}$ \\
\hline Sugar & 0 & 0.02 & 10.31 & 10.39 & 10.34 \\
& 1 & 0.00 & 6.42 & $6.93^{*}$ & 6.62 \\
& 2 & $0.00^{*}$ & $6.20^{*}$ & 7.14 & $6.59^{*}$ \\
\hline
\end{tabular}

Source: Author estimated

Note: * indicates lag order selected by the criterion

FPE: Final prediction error

AIC: Akaike information criterion

SC: Schwarz information criterion

HQ: Hannan-Quinn information criterion

The Schwarz information criteria (SCI) suggests one is the optimum lag, whereas other criterions such as Final Prediction Error (FPE), Akaike Information Criteria (AIC), and Hanann-Quinn Information Criteria ( HQ) suggest to use the optimum lag two in the model estimation. Since, majority criterions suggest the optimum lag two, hence the study uses two optimum lag in the ARDL model estimation. The ARDL model estimated results are shown in Table-5, which has two parts; the first part reports the long-term equilibrium relationship between the selected crops production and the study inputs, whereas the second part reports the error correction results for the short-term equilibrium relations between the study variables. The results indicate that both the paddy and sugarcane production have long-term cointegration with the study input variables. The negative coefficients of rainfall and temperature indicate the negative relationship between crops production and climatic variables. A high rainfall and temperature lead to fall of paddy and sugarcane production. The pesticide consumptions for both the crops are positive and significant, which indicates that a direct relationship exist between crops production and fertilizer consumption in the study area. 
Table 5: Results of ARDL Model for Study Variables

\begin{tabular}{|c|c|c|c|c|}
\hline & \multicolumn{2}{|c|}{ Paddy } & \multicolumn{2}{|c|}{ Sugarcane } \\
\hline Variable & Coefficient & t-Statistic & Coefficient & t-Statistic \\
\hline \multicolumn{5}{|c|}{ Long Run Equation } \\
\hline Area & -0.0273 & -5.34 & $0.91 *(0.07)$ & 13.78 \\
\hline Fertilizer & $0.08 *(0.01)$ & 7.78 & $0.28 *(0.07)$ & 3.93 \\
\hline Rainfall & $-0.06 * *(0.03)$ & 2.13 & $-0.27 *(0.38)$ & -5.11 \\
\hline Temperature & $-0.26 * * *(0.15)$ & -1.97 & $-0.85 * * *(0.46)$ & 1.86 \\
\hline \multicolumn{5}{|c|}{ Short Run Equation } \\
\hline COINTEQ01 & -0.186 & -4.71 & -0.078 & -3.47 \\
\hline D(Production(-1)) & $0.25 \quad(0.19$ & 1.35 & $-0.03(0.08)$ & -0.37 \\
\hline $\mathrm{D}$ (Area) & $0.19 * * \quad(0.11)$ & 1.76 & $0.36 * * \quad(0.18)$ & 1.99 \\
\hline $\mathrm{D}(\operatorname{Area}(-1))$ & $-0.25 * *(0.11)$ & -2.29 & $-0.12 * * *(0.06)$ & -1.91 \\
\hline D(Fertilizer) & $0.02 * * \quad(0.03)$ & -2.05 & $0.44^{*} \quad(0.13)$ & 3.53 \\
\hline $\mathrm{D}($ Fertilizer $(-1))$ & $-0.04 \quad(0.04)$ & -0.92 & $0.09 \quad(0.07)$ & 1.36 \\
\hline D(Rainfall) & $-0.214 * *(0.24)$ & -0.84 & $-0.68 * * \quad(2.01)$ & 1.93 \\
\hline D(Rainfall(-1)) & $0.19 * * *(1.62)$ & 1.72 & $-0.47 * *(1.99)$ & 2.35 \\
\hline D(Temperature) & $-0.66 * *(0.65)$ & 1.96 & $-0.27 \quad(0.35)$ & -1.00 \\
\hline D(Temperature(-1)) & $-0.58 \quad(0.67)$ & -1.00 & $0.25 \quad(0.53)$ & 1.00 \\
\hline
\end{tabular}

Source: Author estimated

The second part indicates the short-term relationship between the crops production and selected inputs in the study area. The error correction coefficients of both the crops are negative and significant at $1 \%$ significance level, which indicates the speed of adjustment for the long-term equilibrium relationship between the study variables. In the short-run both the net shown area and fertilizer consumption have positive relations with the crops production, but there is negative relation between rainfall and temperature and crops production in the study area. The ARDL model bound test results are reported in Table-6, which indicates that the F-statistics of both the crops are significant and above the upper bound, suggest the long-term equilibrium relationship between the crops production and the study selected inputs in the study area.

Table 6: ARDL Cointegration Bound test Results

\begin{tabular}{|c|cc|}
\hline Test Statistics & Estimated Values & Crops \\
\hline F- Statistics & 6.36 & $\begin{array}{c}\text { Paddy } \\
\text { Sugarcane }\end{array}$ \\
\hline \multicolumn{2}{|c|}{ Critical Value Bounds (Pesaran et al., 2001) } \\
\hline Significance Level & Lower Bound (I0) & Upper Bound (I1) \\
\hline $1 \%$ & 4.72 & 5.85 \\
$5 \%$ & 3.88 & 4.61 \\
$10 \%$ & 3.18 & 4.02 \\
\hline
\end{tabular}

Source: Author Estimated 


\section{CONCLUSION}

Climate change is an emerging issue particularly in agricultural research, as it is projected that the climate change unfavorably distresses the agricultural production across the regions. Therefore, the present study aimed to empirically examines the relationship between climate change and agricultural production in the selected districts of Odisha, India using the Panel Autoregressive Distributed Lag (PARDL) model over the period 1993 to 2019. The study has used production inputs such as net shown area, fertilizer consumption, and two climatic variables such as rainfall and average temperature to examine their effect on the selected crops (Paddy and Sugarcane). The study found that the increase of rainfall and temperature affect the crops production negatively in the study are, which is similar to the finding of Chandio et al. (2019), and Guntukula and Phanindra (2020). In order to minimize the impact of climate variables on agricultural productions in the study area, there must have implementation of various policies and adaptive strategies. Since, the timing and adequate quantities of rainfall and temperature has been changed in the study are, the farmers must adopt new crops and diversification strategies to combat the climatic risk.

\section{FUNDING}

This study was supported by the OURIIP Seed Fund Project, sponsored by the Higher Education Council, government of Odisha, India, 2019-20. This study is a part of the project entitled 'Climate Change and household vulnerability to Food Insecurity in Odisha. The study has no conflict of interest.

\section{REFERENCES}

[1] Al-Amin, A.Q., Kari, F., and Alam, G.M. Global Warming and Climate Change: Prospects and Challenges towards Long-Term Policies in Bangladesh. International Journal of Global Warming, 2013, 5 (1), 67-83.

[2] Bhattacharya, T. and Panda R.K. Effect of Climate Change on Rice Yield at Kharagpur, West Bengal. IOSR Journal of Agriculture and Veterinary Science, 2013, 4 (2), 06-12.

[3] Birthal, P., Khan, T., Negi, D.S., and Agarwal, S. Impact of Climate Change on yields of Major Food Crops in India: Implications for Food Security. Agricultural Economic Research Review, 2014, 27 (2), 145-155.

[4] Candio, A A., Jiang, Y., Rehman, A., and Rauf, A. Short and Long-run Impacts of Climate Change on Agriculture: An Empirical Evidence from China. International Journal of Climate Change Strategies and Management, 2019, 12 (2), 201-221.

[5] Chowdhury, I.U.A. and Khan, M.A.E. The Impact of Climate Change on Rice Yield in Bangladesh: A time
Series Analysis. Russian Journal of Agricultural and SocioEconomic Sciences, 2015, 4 (40), 12-28.

[6] Ciscar, J.C., Iglesias, A., Perry, M., Regemorter, D.V. Agriculture, Climate Change and the Global Economy. Working Paper 15, institute for Prospective technological Studies (IPTS), Edificio, Spain, 2012.

[7] Cline, W.R. Global Warming and agriculture: Impact estimates by Country. Centre for Global Development and Peterson institute for International Economics, Washington, DC, 2007.

[8] Deressa, T.T. Measuring the economic impact of climate change on ethiopian agriculture. Policy Research Working Paper 4342. The World Bank Development Research Group, 2002.

[9] Engle and Granger, C.W.J. Cointegration and Error Correction: Representation, Estimation and Testing. Econometrica, 1987, 55, 251-276.

[10] Gillig, D. and McCarl, B.A. Introduction to computable general equilibrium models (CGE). Department of Agricultural Economics, Texas A and M University, 2002.

[11] Guntukula, R., and Goyari, P. Climate Change Effects on the Crop Yield and Its Variability in Telangana, India. Studies in Microeconomics, 2020, 1-30.

[12] Hoda, A., Rajkhowa, P., and Gulati, A. Unleashing Bihar's Agriculture Potential: Sources and Drivers of Agriculture Growth, Working Paper 336, Indian Council for Research on International Economic Relations, March 2017.

[13] Johansen, S., and Juselius, k. Maximum Likelihood Estimation and Inferences on Cointegration- with Applications to the Demand for Money. Oxford Bulletin of Economics and Statistics, 1990, 52, 169-210.

[14] Kaimakamis, Y.EI., Aggelopoulo, S., and Pavloudi, A. Agricultural Production and Climate Change: A Case of Greece. Journal of Environmental Protection and Ecology, 2013, 14 (2), 693-698.

[15] Kumar, K.S. and Parikh, J. Climate Change Impacts on Indian Agriculture: Results from a Crop Modelling Approach. In Dinar and others, eds. Measuring the Impacts of Climate Change on Indian agriculture, World Bank Technical Paper No. 402. Washington, DC: World Bank, 1998.

[16] Kumar, M., Singh, S.H., Pandey, R., Singh, M.P., Ravindranth, N.H., and Kalra, N. Assessing Vulnerability of Forest Ecosystem in the Indian Western Himalayan Region using Trends of Net Primary Productivity. Biodiversity and Conservation, 2019, 28, 2163-2182.

[17] Kurukulasuriya, P. and Mendelsohn, R. A Ricardian Analysis of the Impact of Climate Change on African Cropland. African Journal of Agriculture Resource Economics, 2008, 2, 1-23.

[18] Mariara, J., and Karanja, F.K. The Economic Impact of Climate Change on Kenya Crop Agriculture" a Ricardian Approach. Policy Reearch Working Paper Series 4334, the World Bank.

[19] Mendelsohn, R., Nordhaus, W.D., Shaw, D. The impact of global warming on agriculture: a Ricardian analysis. American Economic Review, 1994, 84, 753-771. 
[20] Mendelson, R., and Dinar, A. Climate, Water, and Agriculture. Land Economics, 2003, 79, 328-341.

[21] Mishra, D., Sahu, N.C., and Sahoo, D. Impact of Climate Change on Agricultural Production of Odisha (India): A Ricardian Approach. Regional Environmental Change, 2015, 16 (2), DOI 10.1007/s10113-015-0774-5.

[22] Mishra, P.K. Socio-Economic Impacts of Climate Change in Odisha: Issues, Challenges and Policy Options. Journal of Climate Change, 2017, 3 (1), 93-107.

[23] Nonan, K.N. and Bedamatta, S. Climate Change, Agriculture, Poverty and Livelihoods: A Status Report. Working Papers 227, Institute for Social and conomic Change, Bangalore, 2012.

[24] Panda, A., Sahu, N., and Behera, S. Impact of Climate Change Variability on Crop Yield in Kalahandi, Bolangir, and Koraput Districts of Odisha, India, Climate, 2019, 7 (11), 1-12.

[25] Parry, M.L., Canziani, O.F., Palutikof, J.P., Van der, Linden P.J., Hanson, C.E. (eds). Climate Change 2007: Impacts, Adaptation and Vulnerability. Contribution of Working Group II to the fourth assessment report of the Intergovernmental Panel on Climate Change, Chapter-2, Cambridge University press, Cambridge, 2007.

[26] Pesaran, M.H., and Shin, Y. An Autoregressive Distributed Lag Modelling Approach to Cointegration Analysis. In Econometrics and Economic Theory in the 20th Century. The Ragnar Frisch Centennial Symposium (S. Strøm, ed.), 371-413. Cambridge University Press, Cambridge.
[27] Putriawant and Asai, k. Questionnaire Survey on Farming Adaptation for Climate Variability in Serang Muncipality, Indonesia. 2016, 67 (2), 59-66.

[28] Rahman, H.M.T., Hickey, G., Ford, J.D., and Egan, M.A. Climate Change Research in Bangladesh: Research Gaps and Implications for Adaptation related Decision Making, Regional Environmental Change, 2018, 18 (70), 1-19.

[29] Rao, C.S., Gopinath, K.A., Prasad, J.V.N.S., Prasannakumar, Singh, A.K. Climate Resilient Villages for Sustainable Food Security in Tropical India: Concept, Process, Technologies, Institutions, and Impacts, Advances in Agronomy, 2016.

[30] Reddy, A.A. Sources of AgriculturalProductivity Growth in Orissa: A District Level Analysis. SSRN Electronov Journal, 2012, 34 (2), 89-105.

[31] Xie, B., Brewer, M.B., Hayes, B.K., McDonald, R.I., Newell, B.R. Predicting Climate Change Risk Perception and Willingness to Act. Journal of Environmental Psychology, 2019, 65, 101331.

[32] Zhai, F., Lin, T., Byambardorj, E. A general equilibrium analysis of the impact of climate change on agriculture in the People's Republic of China. Asian Development Review, 2009, 26, 206-225.

[33] www.desorissa.nic.in

[34] www.imdorissa.gov.in

[35] www.orienvis.nic.in

Appendix

Table 1: Agro-Climate Zones of the Study Area in Odisha

\begin{tabular}{|c|c|c|c|c|}
\hline Sl No. & Zones nd Districts & Climate & Soils & Suitable croping system \\
\hline 1 & $\begin{array}{l}\text { North Central Plateau } \\
\text { (Mayurbhanj) }\end{array}$ & $\begin{array}{l}\text { Hot and Moisture, } \\
\text { humid to sub-humid }\end{array}$ & $\begin{array}{l}\text { Red loam type, } \\
\text { acidic in nature, } \\
\text { light textured }\end{array}$ & $\begin{array}{l}\text { Paddy, mustard, } \\
\text { groundnut, arhar, ragi, } \\
\text { and horsgram }\end{array}$ \\
\hline 2 & $\begin{array}{l}\text { Eastern Coastal Plain } \\
\text { (Balasore, Bhadrak } \\
\text { and Kendrapara) }\end{array}$ & $\begin{array}{l}\text { Hot and Moisture, } \\
\text { humid to sub-humid }\end{array}$ & $\begin{array}{l}\text { Red ; aterite, } \\
\text { alluvial and saline } \\
\text { coastal sandy }\end{array}$ & $\begin{array}{l}\text { paddy, jute, mung, } \\
\text { mustard, groundnut, } \\
\text { sugarcane, etc. }\end{array}$ \\
\hline 3 & \begin{tabular}{|l|} 
Eastern and South \\
Eastern Coastal \\
(Cuttack, Jagatsingpur, \\
Khorda and Puri)
\end{tabular} & $\begin{array}{l}\text { sub-topical, hot and } \\
\text { humid, temperature } \\
\text { lies between } 11.5^{\circ} \mathrm{C} \\
\text { to } 41^{\circ} \mathrm{C} \text {, the average } \\
\text { annual rainfall } \\
1340 \mathrm{~mm} \\
\end{array}$ & $\begin{array}{l}\text { Saline and sandy } \\
\text { soils, alluvial, } \\
\text { lateric, black, and } \\
\text { red lateric soils }\end{array}$ & $\begin{array}{l}\text { paddy, groundnut, } \\
\text { sugarcane, vegetables } \\
\text { and greengram }\end{array}$ \\
\hline 4 & $\begin{array}{l}\text { Mid Central Table } \\
\text { Land Zone (Jajpur and } \\
\text { Nayagarh) }\end{array}$ & $\begin{array}{l}\text { Hot and Dry-sub } \\
\text { humid, temperature } \\
\text { lies between } 14.0^{\circ} \mathrm{C} \\
\text { to } 38.7^{\circ} \mathrm{C} \text {, the } \\
\text { average annual } \\
\text { rainfall is } 1421 \mathrm{~mm} .\end{array}$ & $\begin{array}{l}\text { light textured } \\
\text { lateric- } \\
\text { Rhodustalfs, } \\
\text { mixed of red and } \\
\text { black soils }\end{array}$ & $\begin{array}{l}\text { paddy, pulses, sugarcane, } \\
\text { cotton and vegetables }\end{array}$ \\
\hline
\end{tabular}

Source: Research Bulletin 22, WTCER, Bhubaneswar, Odisha 


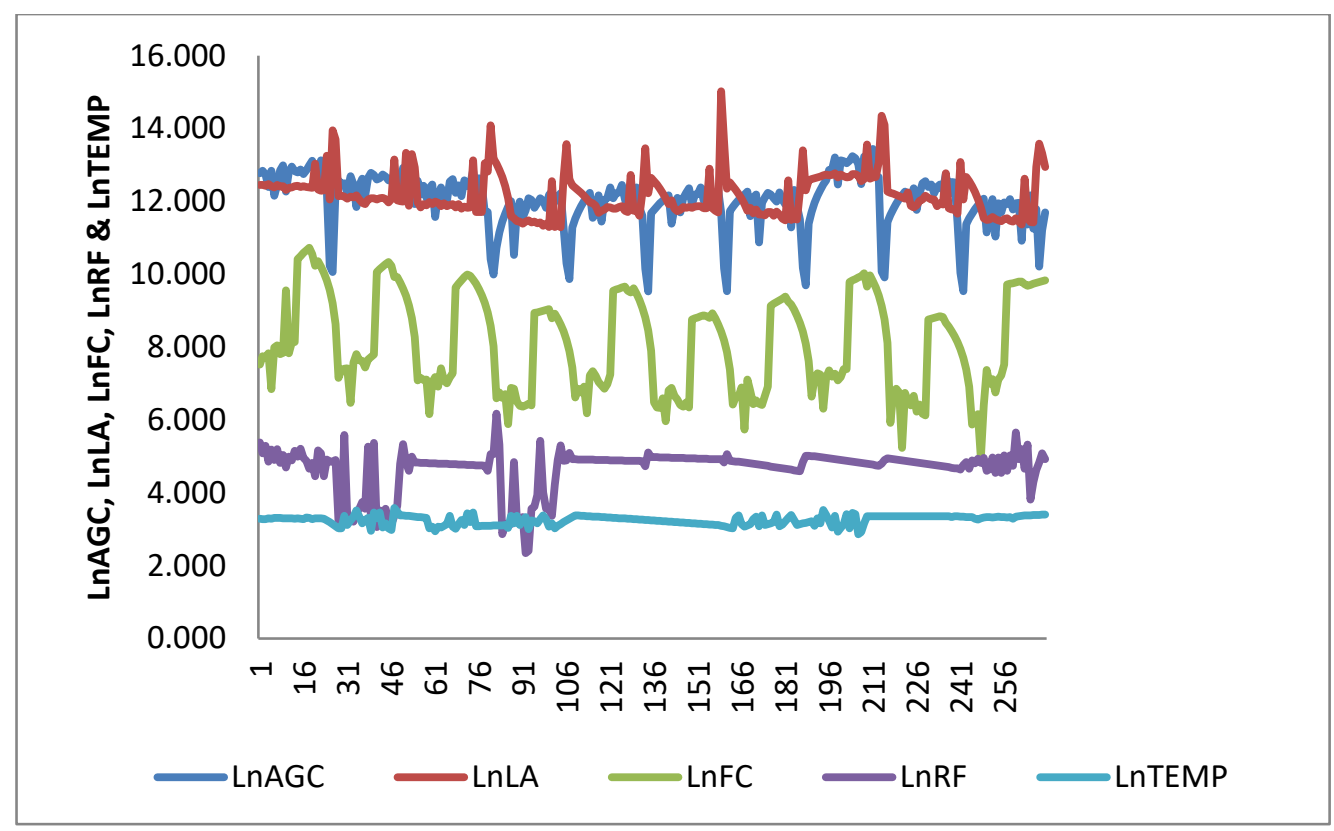

Fig.1: Trends of AGC, LA, FC, RF and TEMP of both Paddy

Source: Author estimated

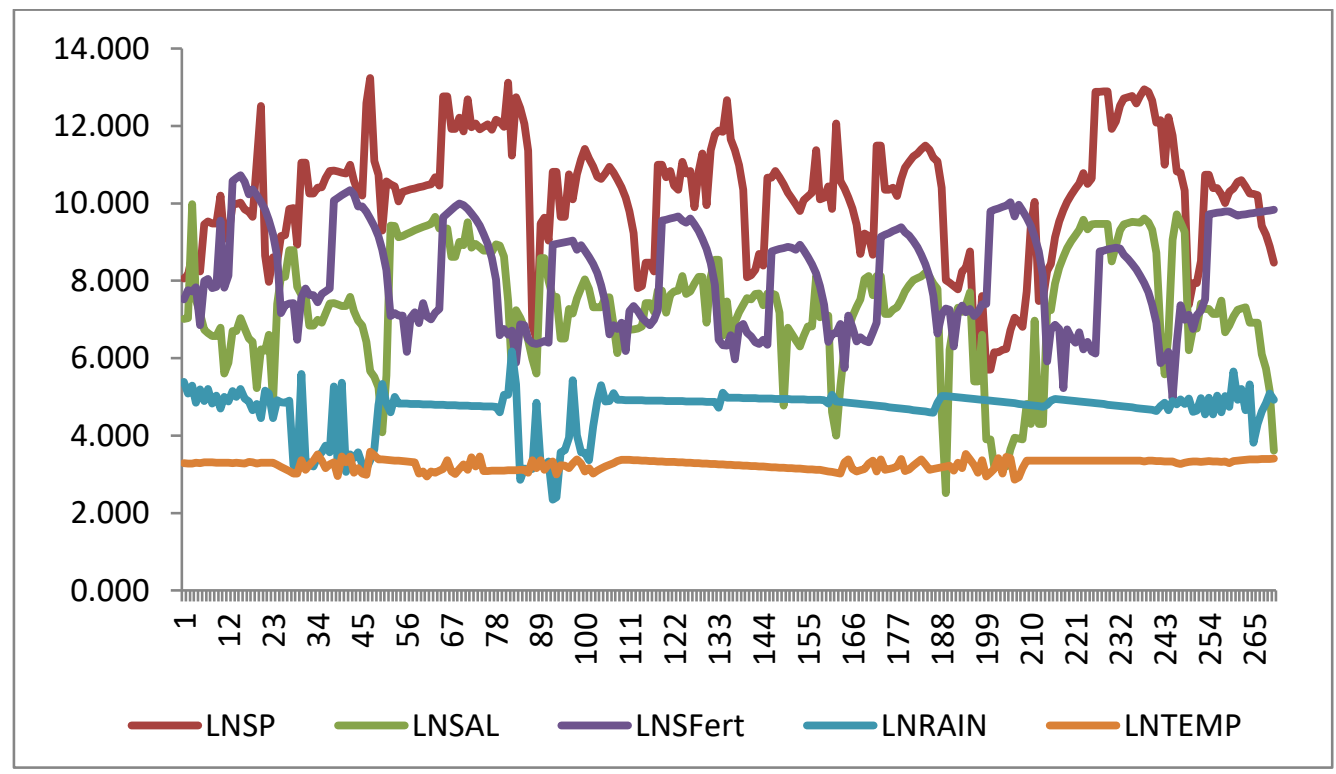

Fig.2: Trend of crops production, net shown area, fertilizer consumption, Rainfall and Average Temperature in Study Area, Odisha

Source: Author estimated 